\title{
ВПЛИВ КОМПЛЕКСНОГО ЛІКУВАННЯ НА ПОКАЗНИКИ СИСТЕМНОї ІМУНОЗАПАЛЬНОӦ АКТИВАЦІЇ У ХВОРИХ НА ПОДАГРУ 3 АРТЕРІАЛЬНОЮ ГІПЕРТЕНЗІЕЮ ТА ОЖИРІННЯМ
}

Резюме. Подагра розглядається як незалежний фактор ризику розвитку серцево-судинних подій та кардіальної смертності. Подагра - інвалідизуюче та поширене захворювання в Європі; його поширеність коливається в межах від 0,9 до 2,5\% залежно від країни. Мета роботи. Оцінити ефеккивність впливу лозартану та мельдонію дигідрату на показники СІА у хворих на подагру з коморбідними станами.

Матеріали та методи. Обстежено 80 хворих на ЕАГ II стадії 2-го ступеня в поєднанні з ожирінням та подагрою.

Результати та обговорення. Показники СІА під впливом стандартної терапії в динаміці достовірно не змінювались. Лозартан на тлі стандартної терапії достовірно знижував рівень IL-6. Після 6-місячного лікування його концентрація в крові зменшилась на $10,81 \%(p<0,05)$, а рівень СРП - на $17,31 \%(p<0,05)$. Мельдонію дигідрат достовірно знижував рівень СРП вже після 1 місяця лікування на 9,22\% ( $<0,01)$, а після 6 місяців — на 11,48\% ( $<<0,001)$. Слід відзначити, що динаміка показників СІА була найбільш вираженою при поєднанні лозартану та мельдонію дигідрату. Про це свідчить зниження рівня СРП у сироватці крові на 23,39\% $(p<0,001)$ через 1 місяць лікування, а через 6 місяців — на 35,01\% ( $\mathrm{p}<0,001)$, а вмісту IL-6 відповідно на 40,15\% ( $\mathrm{p}<0,001)$ та $62,10 \%(p<0,001)$.

Висновки. Встановлено, що поєднане застосування лозартану та мельдонію дигідрату на тлі стандартної терапії мало значно більшу есрективність щодо зниження СІА порівняно з роздільним прийомом цих препаратів.

Ключові слова: подагра, артеріальна гіпертензія, ожиріння, системна імунозапальна активація.

УДК: $615.272+616.12-008.331 .1++616-$ $056.52++616.72-002.78$

DOI: 10.31793/2709-7404.2021.2-2.45

(C) М.О. Вацеба, Н.М. Середюк, І.П. Вакалюк

Надійшла до редакції 04.06.2021

Адреса для листування (Correspondence): Івано-Франківський національний медичний університет, вул. Галицька, 2, м. Івано-Франківськ, 76018, Україна.E-mail: zdovado@ukr.net 


\title{
The influence of complex treatment on indicators of systemic immuno-inflammatory activation in patients with gout with arterial hypertension and obesity
}

\author{
M.O. Vatseba, N.M. Seredyuk, I.P. Vakaliuk \\ Ivano-Frankivsk National Medical University, Ivano-Frankivsk
}

\begin{abstract}
The aim of the study was to evaluate the effect of Iosartan and meltedonium dihydrate on the parameters of systemic immune activation in patients with essential hypertension with obesity and gout. The study involved 80 patients with essential hypertension II stage 2 degrees combined with obesity and gout. Indicators of systemic immune activation under the influence of standard therapy in the dynamics did not significantly change. Losartan on the background of standard therapy significantly lowered the level of IL-6. After 6 months of treatment, its concentration in the blood decreased by $10.81 \%(p<0.05)$, and the level of CRP — by $17.31 \%(p<0.05)$. Meldonium dihydrate significantly reduced the CRP level after 1 month of treatment by $9.22 \%(p<0.01)$, and after 6 months - by $11.48 \%(p<0.001)$. It should be noted that the dynamics of systemic immun activation rates was most pronounced while combination losartan and meltedium dihydrate. This is evidenced by a decrease level of the CRP in the blood in $23.39 \%(p<0.001)$ after 1 month of treatment, and after 6 months by $35.01 \%(p<0.001)$ and IL-6 content, respectively, by $40,15 \%(p<0.001)$ and $62.10 \%$ $(p<0.001)$. Thus, it has been found that the combined use of losartan and meltedonium dihydrate against the background of standard therapy was much more effective in reducing the systemic immune activation compared with the separate administration of these drugs.
\end{abstract}

Keywords: gout, arterial hypertension, obesity, systemic immunoactive activation.

Подагра розглядається як незалежний фрактор ризику розвитку серцево-судинних подій та кардіальної смертності. Подагра - інвалідизуюче та поширене захворювання в Європі; його поширеність коливається в межах від 0,9 до 2,5\% залежно від країни [10]. Артеріальна гіпертензія (АГ) - актуальна проблема сучасної охорони здоров'я України, що має істотний вплив на показники серцево-судинної захворюваності та смертності $[2,8]$. Коморбідність АГ залишається недостатньо вивченою проблемою [3, 4]. На тлі її широкої поширеності спостерігається збільшення осіб, хворих на АГ, з ожирінням та подагрою [10]. Важливо знайти спільні патогенетичні механізми, які б зумовлювали розвиток та прогресування АГ, ожиріння та подагри. Одними з таких є зміни показників системної імунозапальної активації (CIA) $[3,9,10]$. Вважається, що хронічне системне запалення викликає ушкодження ендотелію кровоносних судин. Унаслідок цього синтез оксиду азоту припиняється в стінці судини й активізується ренін-ангіотензин-альдостеронова система (РАAC) [9]. Літературні дані свідчать про зв'язок між АГ і запальним процесом, який поглиблюється на тлі надмірної маси тіла та подагри $[1,7]$. Найвагомішими біологічними маркерами запального процесу є СРП, прозапальні цитокіни (IL-6). При хронічній активації імунної відповіді спостерігається активація «прозапальних» елементів: ФНП- $\alpha, \mathrm{IL}-1 \beta, 6$, 7, 8, 12, 15 - і відносна недостатність синтезу «протизапальних»: IL-4 та 10, антагоніста рецептора IL-1, трансформуючого фрактора росту 1. Дисбаланс цитокінової мережі призводить до розвитку дисфункції ендотелію, вазоконстрикції, зростання перекисного окиснення ліпідів, гіперкоагуляції [9]. Лікування хворих на тлі метаболічних факторів ризику потребує агресивної терапії. Особлива увага приділяється антигіпертензивним препаратам, які мають позитивний метаболічний ефект. Зважаючи на багатогранність патогенетичних механізмів поєднання АГ, ожиріння та подагри, терапія також повинна бути багатоцільовою. Тому логічним та перспективним напрямком $€$ активний пошук лікарських засобів і їх комбінацій, здатних ефективно впливати на різні ланки формування АГ, зокрема на показники СІА.

Мета роботи. Оцінити есективність впливу лозартану та мельдонію дигідрату на показники CIA у хворих на подагру з коморбідними станами. 


\section{Матеріали та методи}

У дослідження включено 80 хворих на подагру з ЕАГ II стадії 2-го ступеня та ожирінням. Дослідження проводилися на базі ревматологічного відділення Івано-Франківської центральної міської клінічної лікарні та відділення артеріальної гіпертензії Івано-Франківського обласного клінічного кардіологічного диспансеру. Перша група - 20 хворих, котрі отримували стандартну терапію: блокатори кальцієвих каналів - амлодипін 5-10 мг/добу, статин - аторвастатин 10-20 мг/добу, нетіазидний діуретик - індапамід 2,5 мг зранку, алопуринол 100-300 мг/добу. Друга група - 20 хворих, окрім стандартної терапії, отримували БРА II — лозартан 50-100 мг/ добу (Лоріста, Фармацевтична фірма KRKA, Словенія). Третя група - 20 хворих, окрім стандартної терапії, отримували мельдоній дигідрат (Метамакс, «Дарниця», Україна) - 5 мл 10\% розчину розводили в 15 мл 0,9\% розчину натрію хлориду, вводили внутрішньовенно струминно протягом 10 днів, із подальшим переходом на капсульну форму -250 мг 3 рази на добу протягом 1 місяця внутрішньо. Четверта група - 20 хворих, котрі отримували комбіноване лікування стандартною терапією із лозартаном та мельдонієм дигідратом. Здійснили клінічне обстеження пацієнтів. СІА оцінювали шляхом вмісту IL-6, CPП у крові, які визначали імуноферментним методом.

Статистичне опрацювання результатів виконували за допомогою програмного забезпечення - табличного процесора Microsoft Excel i пакета прикладних програм Statistica v.6.0 (StatSoft, USA). Для груп вираховували середні значення показників та їхні стандартні похибки ( $\mathrm{M} \pm \mathrm{m}$, де $\mathrm{M}$ - середня величина, $\mathrm{m}$ їі стандартна похибка). Вірогідність розходження середніх величин оцінювали за допомогою парного t-критерію Стьюдента.

\section{Результати та обговорення}

У табл. 1 наведено дані про вплив стандартної терапії на показники СІА. Встановлено, що вона суттєво не впливає на рівень СРП та IL-6 ( $p>0,05)$.

Після 6-місячного лікування з використанням лозартану вдалося досягти достовірного зниження рівня IL-6 в 1,12 раза $(p<0,05)$, а СРП - в 1,21 раза $(p<0,05)$ (табл. 2). Як відомо, СІА супроводжується пошкодженням ендотелію судин, що призводить до прогресування диссрункції ендотелію. Вплив лозартану на CIA може бути пов'язаний із блокадою активності РАAC і нейтралізацією дії такого потужного прозапального фактора, як ангіотензин II, а також зі зменшенням оксидантного стресу та диссрункції ендотелію. Включення до стандартної терапії таких хворих лозартану приводить не тільки до підвищення ефективної антигіпертензивної терапії, але й чинить протизапальну дію.

При застосуванні мельдонію дигідрату не спостерігалось достовірних змін IL-6 (табл. 3). Водночас СРП зменшувався як через місяць, так і через 6 місяців такої терапії. Так, після місяця лікування СРП знизився на 9,22\% $(p<0,01)$, а після 6 місяців - на 11,48\% ( $p<0,001)$.

Під впливом лозартану та мельдонію дигідрату вже після 1 місяця СРП був меншим на $23,39 \%$ ( $p<0,001)$, а після 6 місяців — на $35,01 \%$ $(p<0,001)$ (табл. 4). Концентрація IL-6 після 1 міс. лікування знизилась на 40,15\% ( $p<0,001)$, а після 6 міс. - на 62,10\% ( $><0,001)$. Таким чином, після 6-місячної комбінованої терапії з лозартаном та мельдонієм дигідратом відмічено статистично значуще зменшення концентрації окремих прозапальних цитокінів.

Згідно з нашим дослідженням показники CIA під впливом стандартної терапії в динаміці достовірно не змінювались. Відсутність впливу традиційної антигіпертензивної терапії (периндоприл, амлодипін та індапамід) на СРП та IL-6 крові відмітили Радченко Г.Д., Муштенко Л.О. [6]. Міщенко Л.А. та співавт. [5] також не спостерігали позитивного впливу базового лікування з включенням амлодипіну на вміст СРП у хворих на ЕАГ. У нашому дослідженні лозартан достовірно знижував рівень IL-6. Зменшення вираженості системного запалення, що проявлялось у достовірному зменшенні рівня СРП під впливом терапії лозартаном та периндоприлом, встановили Безродний В.В. та співавт. [5], водночас лерканідипін суттєво не впливав на активність неспецисіччного системного запалення. Даних про вплив мельдонію дигідрату на інтенсивність показників CIA не знайдено. Можливо, доведені протизапальні есекти в нашому дослідженні пов'язані із здатністю мельдонію дигідрату підвищувати активність захисних антиоксидантних ферментів та знижувати активність перекисного окиснення ліпідів. При визначенні впливу мельдонію дигідрату та лозартану на активність імунного запалення встановлена протизапальна есрективність обох препаратів, що посилюється при комбінованому застосуванні. Слід 


\section{Таблиця 1}

Динаміка показників системної імунозапальної активації під впливом стандартної терапії (M士m)

\begin{tabular}{llll} 
Показник, & \multicolumn{2}{l}{ Час спостереження } \\
\cline { 2 - 4 } од. виміру & $\begin{array}{l}\text { До лікування } \\
(\mathbf{n = 1 3 )}\end{array}$ & $\begin{array}{l}\text { Через 1 місяць } \\
(\mathbf{n}=\mathbf{1 3})\end{array}$ & $\begin{array}{l}\text { Через 6 місяців } \\
\mathbf{( n = 1 3 )}\end{array}$ \\
\hline ІЛ-6, пг/мл, & $32,2 \pm 0,95$ & $28,95 \pm 3,33^{*}$ & $32,31 \pm 0,88^{*}$ \\
$\Delta, \%$ & & $-10,09$ & $+0,34$ \\
СРП, мг/л, & $12,38 \pm 0,30$ & $12,19 \pm 1,65^{\star}$ & $12,24 \pm 0,89^{\star}$ \\
$\Delta, \%$ & & $-1,53$ & $-1,13$ \\
\hline
\end{tabular}

Примітки: 1. p - достовірність різниці даних порівняно з величинами до лікування $\left.{ }^{*}-p>0,05\right) .2 . \Delta-$ різниця показника порівняно з величинами до лікування, \%.

\section{Таблиця 2}

Динаміка показників системної імунозапальної активації під впливом стандартної терапії в поєднанні з лозартаном $(\mathrm{M} \pm \mathrm{m})$

\begin{tabular}{llll} 
Показник, & \multicolumn{2}{l}{ Час спостереження } \\
\cline { 2 - 4 } од. виміру & $\begin{array}{l}\text { До лікування } \\
(\mathbf{n = 1 3 )}\end{array}$ & $\begin{array}{l}\text { Через 1 місяць } \\
(\mathbf{n = 1 3})\end{array}$ & $\begin{array}{l}\text { Через 6 місяців } \\
(\mathbf{n = 1 3})\end{array}$ \\
\hline ІЛ-6, пг/мл & $30,79 \pm 0,79$ & $29,93 \pm 1,65^{\star}$ & $27,46 \pm 1,33^{* *}$ \\
$\Delta, \%$ & & $-2,79$ & $-10,81$ \\
СРП, мг/л & $11,67 \pm 0,17$ & $11,49 \pm 1,98^{*}$ & $9,65 \pm 0,97^{* *}$ \\
$\Delta, \%$ & & $-1,54$ & $-17,31$ \\
\hline
\end{tabular}

Примітки: 1. p - достовірність різниці даних порівняно з величинами до лікування $\left({ }^{*}-p>0,05 ;{ }^{*}-p<0,05\right) .2 . \Delta-$ різниця показника порівняно з величинами до лікування, \%.

\section{Таблиця 3}

Динаміка показників СІА під впливом стандартної

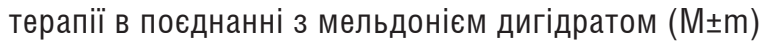

\begin{tabular}{llll}
\hline Показник, & \multicolumn{2}{l}{ Час спостереження } \\
\cline { 2 - 4 } од. виміру & $\begin{array}{l}\text { До лікування } \\
(\mathbf{n}=13)\end{array}$ & $\begin{array}{l}\text { Через 1 місяць } \\
(\mathbf{n}=13)\end{array}$ & $\begin{array}{l}\text { Через 6 місяців } \\
(\mathbf{n}=13)\end{array}$ \\
\hline ІЛ-6, пг/мЛ & $32,04 \pm 1,16$ & $28,59 \pm 2,18^{*}$ & $28,64 \pm 1,63^{*}$ \\
$\Delta, \%$ & & $-10,76$ & $-10,61$ \\
СРП, мг/л & $11,93 \pm 0,19$ & $10,83 \pm 0,35^{\star *}$ & $10,56 \pm 0,32^{*}$ \\
$\Delta, \%$ & & $-9,22$ & 11,48 \\
\hline
\end{tabular}

Примітки: 1. p - достовірність різниці даних порівняно з величинами до лікування $\left({ }^{*}-p>0,05 ;{ }^{* *}-p<0,01 ; *-p<0,001\right) .2 . \Delta-$ різниця показника порівняно з величинами до лікування, \%.

\section{Таблиця 4}

Динаміка адипокінів під впливом стандартної терапії в поєднанні з лозартаном та мельдонієм дигідратом $(\mathrm{M} \pm \mathrm{m})$

\begin{tabular}{|c|c|c|c|}
\hline \multirow{2}{*}{$\begin{array}{l}\text { Показник, } \\
\text { од. виміру }\end{array}$} & \multicolumn{3}{|c|}{ Час спостереження } \\
\hline & $\begin{array}{l}\text { До лікування } \\
(\mathrm{n}=13)\end{array}$ & $\begin{array}{l}\text { Через } 1 \text { місяць } \\
(n=13)\end{array}$ & $\begin{array}{l}\text { Через } 6 \text { місяців } \\
\text { (n=13) }\end{array}$ \\
\hline $\begin{array}{l}\text { ІЛ-6, пг/мл } \\
\Delta \%\end{array}$ & $32,85 \pm 1,06$ & $\begin{array}{l}19,66 \pm 2,66^{* \star *} \\
-40,15\end{array}$ & $\begin{array}{l}12,45 \pm 1,77^{\star * *} \\
-62,10\end{array}$ \\
\hline $\begin{array}{l}\text { СРП, мг/л } \\
\Delta \%\end{array}$ & $12,14 \pm 0,18$ & $\begin{array}{l}9,30 \pm 0,65^{\star * *} \\
-23,39\end{array}$ & $\begin{array}{l}7,98 \pm 0,44^{* * *} \\
-35,01\end{array}$ \\
\hline
\end{tabular}

Примітки: 1. p - достовірність різниці даних порівняно з величинами до лікування $\left(^{*}-p>0,05 ;{ }^{* *}-p<0,05 ;{ }^{* * *}-p<0,001\right) \cdot 2 . \Delta-$ різниця показника порівняно з величинами до лікування, \%. відмітити, що динаміка показників CІА була найбільш вираженою при використанні такої комбінації лікування.

Таким чином, встановлено, що поєднане застосування лозартану та мельдонію дигідрату на тлі стандартної терапії мало значно більшу ефективність щодо зниження CIA порівняно з роздільним прийомом цих препаратів.

\section{Висновки}

1. Отже, поєднане застосування лозартану та мельдонію дигідрату в поєднанні зі стандартною терапією має додаткові переваги в лікуванні хворих на подагру з ЕАГ ІІ стадії та ожирінням, а також дозволяє здійснювати моніторинг за ефективністю терапії та уточнювати прогноз захворювання.

2. Сучасний підхід до підвищення ефективності лікування хворих на подагру в поєднанні з АГ та ожирінням полягає в комбінуванні метаболічних й антигіпертензивних препаратів з урахуванням можливості зниження інших серцево-судинних факторів ризику, до яких можна віднести активацію синтезу цитокінів.

3. Отримані дані свідчать про доцільність застосування комбінації зі стандартною терапією лозартану та мельдонію дигідрату як протизапальної терапії у хворих на подагру з ЕАГ та ожирінням. 


\section{Список використаної літератури}

1. Cibičková L', Langová K, Vaverková H et al. Correlation of uric acid levels and parameters of metabolic syndrome. Physiol. Res. 2017;66(3):481-487.

2. Класифбікація та стандарти надання медичної допомоги хворим на артеріальну гіпертензію Асоціації кардіологів України. Робоча група з артеріальної гіпертензії української асоціації кардіологів. Артеріальна гіпертензія. 2018;4(60):28-32.

3. Kuwabara M. Hyperuricemia, Cardiovascular Disease, and Hypertension. Pulse (Basel). 2016;3(3-4):242-252.

4. Martínez-Quintana E, Tugores A, Rodríguez-González F. Serum uric acid levels and cardiovascular disease: the Gordian knot. J. Thorac. Dis. 2016;8(11):1462-1466.

5. Міщенко ЛА. Вплив антигіпертензивних препаратів на прозапальні та метаболічні фрактори серцево-судинного ризику у хворих на гіпертонічну хворобу / ЛА Міщенко, ЄП Свіщенко, ВП Безродний. Галицький лікарський вісник. 2012;19(4):55-58.

6. Радченко ГД. Регрес ураження органів-мішеней на тлі терапії фіксованою комбінацією периндоприлу та амлодипіну в пацієнтів з артеріальною гіпертензією залежно від наявності ішемічної хвороби серця / ГД Радченко, ЛО Муштенко, ЮМ Сіренко. Український кардіологічний журнал. 2017;4:32-46.

7. Reviño-Becerra A. Uric Acid: The unknown uremic toxin. Contrib. Nephrol. 2018;192(1):25-33.

8. Сіренко ЮМ. Про нові європейські рекомендації з артеріальної гіпертензії після їх першої презентації (коментар). Артеріальна гіпертензія. 2018;3(59):19-22.

9. Стрільчук ЛМ. Особливості адипоцитокінової регуляції в осіб із гіпертонічною хворобою та підвищеною масою тіла. Артеріальна гіпертензія. 2017;3(53):71-72.

10. Тащук ВК. Коморбідність, серцево-судинна патологія і лікування гіперурикемії - чи запобігає захворюванню алопуринол? (огляд літератури) / ВК Тащук, Васек Обейд Аль Салама Мухамед. Буковинський медичний вісник. 2016;20(2). 